$\delta$ ELT $\Delta$

Jurnal Ilmiah Pendidikan Matematika

p.ISSN: 2303 -3983 e.ISSN:2548-3994

Vol. 6 No. 2 Juli 2018 Hal $33-40$

\title{
ANALISIS SOAL-SOAL PADA BUKU TEKS MATEMATIKA KURIKULUM 2013 EDISI REVISI TAHUN 2014 KELAS XI BERDASARKAN KEMAMPUAN PENALARAN MATEMATIKA
}

\author{
Dyan Falasifa Tsani \\ ${ }^{1}$ Universitas Islam Negeri Walisongo, \\ dyantsani@gmail.com
}

\begin{abstract}
Abstrak
Proses bernalar sangat erat kaitannya dengan dunia matematika, khususnya dalam hal pemecahan masalah. Pada realitanya di sekolah-sekolah dalam berlatih memecahkan masalah para pendidik biasanya menggunakan buku teks untuk mengukurnya apakah siswa sudah memahami apa yang telah disampaikan oleh pendidik atau belum. Untuk itu perlu diketahui apakah buku-buku teks matematika yang telah beredar telah mengarahkan siswa untuk meningkatkan kemampuan penalaran matematika atau belum. Metode penelitian yang digunakan adalah deskriptif kualitatif, dengan subjek penelitian adalah soal-soal Uji Kompetensi yang ada pada buku teks matematika Kurikulum 2013 edisi revisi tahun 2014 kelas XI. Pengumpulan data yang dilakukan menggunakan metode dokumentasi. Pedoman analisis soal berdasarkan indikator kemampuan penalaran matematika menurut NCTM. Hasil analisis diperoleh bahwa dari 225 soal yang dianalisis terdapat 76 soal yang memenuhi indikator 1, 110 soal memenuhi indikator 2, 30 soal memenuhi indikator 3, dan 183 soal memenuhi indikator 4. Hasil analisis juga diperoleh berdasarkan kriteria kemampuan penalaran matematika, dari 225 soal yang dianalisis hanya terdapat 8 soal yang tidak memenuhi indikator kemampuan penalaran matematika dengan presentase $3,56 \%$. Sedangkan sisanya ada 217 soal yang memenuhi indikator kemampuan penalaran matematika dengan presentase $96,45 \%$, dengan rincian 49 soal dengan presentase $21,78 \%$ memiliki kriteria baik, 80 soal dengan presentase $35,56 \%$ memiliki kriteria sedang, dan 88 soal dengan presentase $39,11 \%$ memiliki kriteria kurang.
\end{abstract}

Kata kunci: Analisis soal, buku teks matematika kurikulum 2013 kelas XI, kemampuan penalaran

\begin{abstract}
The process of reasoning has a very strong connection with mathematic world, especially on problem solving skills. But in real life, teachers usually use textbook to measure how much do their students understand materials taught by the teachers. Hence, it is necessary to understand completely do the widely used mathematic textbook has led students to increase their mathematic reasoning skills. The method used were descriptive qualitative, with Competency Test's problems in 2013 Curriculum text book revised in 2014 for $1^{\text {th }}$ grade used for research subjects. Documentation method was used as data collection method. Problems analysis guide was based on mathematic reasoning skills indicator according to NCTM. The analysis result tells that from 225 problems analyzed there were 76 problems fulfilled the indicator 1, 110 problems fulfilled the indicator 2, 30 problems fulfilled the indicator 3 and 183 problems fulfilled the indicator 4. Analysis also shows that based on mathematic reasoning skills, from 225 problems there were only 8 problems haven't fulfilled the mathematic reasoning skills with 3,56\% presentation number. While the rest there were 217 problems have fulfilled the mathematic reasoning skills with $96,45 \%$ presentation number with 49 problems with $21,78 \%$ presentation number have a good criteria, 80 problems with $35,56 \%$ have an average criteria and 88 problems or $39,11 \%$ have a low criteria. Keywords: problems analysis, 2013 Curriculum Mathematic Textbook for $11^{\text {th }}$ grade, reasoning skills.
\end{abstract}

\section{A. Pendahuluan}

Kurikulum adalah (Kemendikbud, 2012) seperangkat rencana dan pengaturan mengenai tujuan, isi, dan bahan pelajaran serta cara yang digunakan sebagai pedoman penyelenggaraan kegiatan pembelajaran untuk mencapai tujuan pendidikan tertentu. 
Isi atau konten kurikulum adalah kompetensi yang dinyatakan dalam Kompetensi Inti (KI) mata pelajaran dan dirinci lebih lanjut kedalam Kompetensi Dasar (KD). Isi kurikulum merupakan bahan kajian dan pelajaran untuk mencapai tujuan pendidikan nasional yang meliputi bahan kajian dan mata pelajaran. Isi kurikulum adalah mata pelajaran pada proses belajar mengajar, seperti pengetahuan keterampilan dan nilai-nilai yang di asosiasikan dengan mata pelajaran (dalam Nikawanti 2013, diakses pada 30 Maret 2017). Salah satu dari sekian mata pelajaran yang ada adalah matematika. Berdasarkan Permendiknas Nomor 22 Tahun 2006 tentang standar isi (Seperti dikutip dalam Utami dkk, 2014), tujuan pembelajaran matematika adalah agar siswa mampu untuk:

1. Memahami konsep matematika, menjelaskan keterkaitan antar konsep dan mengaplikasikan konsep atau logaritma, secara luwes, akurat, efisien, dan tepat dalam pemecahan masalah

2. Menggunakan penalaran pada pola dan sifat, melakukan manipulasi matematika dalam membuat generalisasi, menyusun bukti, atau menjelaskan gagasan dan pernyataan matematika

3. Memecahkan masalah yang meliputi kemampuan memahami masalah, merancang model matematika, menyelesaikan model, dan menafsirkan solusi yang diperoleh

4. Mengomunikasikan gagasan dengan simbol, tabel, diagram, atau media lain untuk memperjelas keadaan atau masalah

5. Memiliki sikap menghargai kegunaan matematika dalam kehidupan, yaitu memiliki rasa ingin tahu, perhatian, dan minat dalam mempelajari matematika, serta sikap ulet dan percaya diri dalam pemecahan masalah.

Komponen utama pada kurikulum disebutkan dalam UU Nomor 20 Tahun 2003 tentang Sistem Pendidikan Nasional (seperti dikutip dalam Mustofa, $t$ ) yaitu isi dan bahan pelajaran, cara yang digunakan sebagai pedoman penyelenggaraan kegiatan pembelajaran, dan tujuan pendidikan yang akan dicapai. Dimana isi dan bahan pelajaran terdapat berbagai macam komponen lagi didalamnya, diantaranya Kompetensi Inti, Kompetensi Dasar, materi ajar yang semuanya itu dapat ditemukan dalam buku teks pelajaran. Peraturan Pemerintah Nomor 32 Tahun 2013 tentang Standar Nasional Pendidikan perubahan Nomor 19 Tahun 2005, buku teks pelajaran adalah sumber pembelajaran utama untuk mencapai kompetensi dasar dan kompetensi inti (Adilah, 2015). Pada kurikulum 2013 buku teks yang digunakan adalah buku siswa yang telah disediakan oleh pemerintah untuk mendukung kurikulum yang berlaku. Strategi ini memberikan jaminan terhadap kualitas isi atau bahan ajar dan penyajian buku. 
Pada buku teks terdapat Kompetensi Inti (KI) dan Kompetensi Dasar (KD) yang harus dicapai pada masing-masing jenjang sekolah. Pada Kompetensi Inti yang terdapat di jenjang Sekolah Menengah Atas (SMA) terdapat 4 sikap yang harus dilaksanakan sesuai rancangan pemerintah, yaitu KI 1 tentang sikap spiritual, KI 2 tentang sikap sosial, KI 3 tentang sikap pengetahuan, dan KI 4 tentang sikap keterampilan. Pada mata pelajaran matematika KI 4 tentang sikap keterampilan terdapat beberapa aspek yang harus dicapai dan salah satunya adalah menalar. Dimana menalar merupakan salah satu cara berpikir tingkat tinggi yang harus dicapai pada jenjang SMA.

Apapun yang berhubungan dengan keilmuan pasti semuanya tidak akan ada tanpa proses penalaran dan penelitian. Konsep-konsep yang muncul dalam setiap bidang ilmu pasti merupakan hasil dari suatu proses penalaran, terlebih dalam bidang matematika. Kemampuan memahami materi matematika seseorang tidak dapat dilepaskan dari kemampuan penalaran, dengan kata lain materi matematika akan mudah dipahami dengan adanya kemampuan nalar yang baik.

Matematika diberikan kepada semua siswa tanpa terkecuali agar terlatih berpikir secara logis, analisis, sistematis, dan kreatif. Dengan kompetensi-kompetensi tersebut diharapkan siswa dapat memiliki kemampuan menerima, mengelola, dan memanfaatkan pengetahuan yang diperolehnya. Latihan berpikir, merumuskan masalah serta mengambil kesimpulan akan membantu siswa untuk mengembangkan pemikiran dan intelegensinya. Dengan demikian, semakin banyak siswa berlatih memecahkan masalah matematis maka akan semakin berkembang cara berpikirnya (Rosita).

Penalaran siswa dapat ditingkatkan melalui latihan-latihan yang memerlukan aktivitas penalaran seperti pemecahan masalah matematika. Menurut Suharnan (seperti dikutip dalam Sukayasa, 2009) penalaran merupakan kemampuan berpikir atau keterampilan intelektual yang dapat ditingkatkan melalui latihan-latihan secara langsung dan intensif, dan yang dimaksud dengan latihan penalaran adalah serangkaian tugas mengerjakan soal-soal atau problem-problem penalaran yang dilakukan secara berulangulang sehingga seseorang menjadi lebih trampil dalam menarik kesimpulan menurut prinsip-prinsip penalaran. Proses bernalar sangat erat kaitannya dengan dunia matematika, khususnya dalam hal pemecahan masalah. Pada realitanya di sekolah-sekolah dalam berlatih memecahkan masalah para pendidik biasanya menggunakan buku teks untuk mengukurnya apakah siswa sudah memahami apa yang telah disampaikan oleh pendidik atau belum. Untuk itu perlu diketahui apakah buku-buku teks matematika yang telah beredar khusunya buku keluaran pemerintah telah mengarahkan siswa untuk meningkatkan kemampuan penalaran atau belum. 
Penelitian tentang analisis pada buku keluaran pemerintah telah dilakukan sebelumnya oleh Nurul Adilah mahasiswi Pendidikan Matematika Universitas Islam Negeri Walisongo Semarang dengan judul “Analisis Soal dalam Buku Siswa Matematika Kurikulum 2013 Kelas VIII Semester I Berdasarkan Dimensi Kognitif dari Trends in International Mathematics and Science Study(TIMSS)". Hasil penelitian diperoleh bahwa dari 212 soal yang dianalisis diperoleh 36 soal hanya mencapai tingkat kognitif pada domain knowing dengan persentase $16.98 \%$, 114 soal sudah mencapai tingkat kognitif pada domain applying dengan persentase $53.77 \%$ dan 62 soal sudah mencapai tingkat kognitif pada domain reasoning dengan persentase $29.25 \%$. Sejalan dengan hasil dari penelitian tersebut yang membuktikan bahwa aspek reasoning atau penalaran telah tercapai pada soal-soal buku keluaran pemerintah di jenjang Sekolah menengah Pertama (SMP), maka pada penelitian ini akan dianalisis apakah aspek penalaran juga tercapai pada soalsoal buku keluaran pemerintah di jenjang Sekolah Menengah Atas (SMA) atau belum.

Berdasarkan uraian-uraian yang telah disampaikan maka peneliti tertarik untuk mengambil judul penelitian "Analisis Soal-soal pada Buku Teks Matematika Kurikulum 2013 Edisi Revisi Tahun 2014 Kelas XI Berdasarkan Kemampuan Penalaran Matematika”.

\section{B. Metode Penelitian}

Jenis penelitian yang digunakan adalah penelitian kualitatif kepustakaan. Data dari penelitian ini adalah soal-soal yang terdapat pada buku teks matematika Kurikulum 2013 edisi revisi tahun 2014 kelas XI, sedangkan sumber datanya adalah buku teks matematika Kurikulum 2013 edisi revisi tahun 2014 kelas XI. Penelitian dilakukan pada bulan Juli hingga bulan Agustus tahun 2017. Pada penelitian ini diperlukan batasan sehingga penelitian akan fokus pada satu tujuan, sehingga batasan yang peneliti ambil yaitu hanya fokus pada soal-soal yang ada pada buku teks matematika Kurikulum 2013 edisi revisi tahun 2014 kelas XI yang akan dianalisis berdasarkan indikator kemampuan penalaran matematika dari NCTM (National Council of Teachers of Mathematics), yaitu (NCTM, 2000):

1. Mengenali penalaran dan pembuktian sebagai aspek fundamental matematika

2. Membuat dan menyelidiki dugaan matematis

3. Mengembangkan dan mengevaluasi argumen matematika dan pembuktian

4. Memilih dan menggunakan berbagai jenis penalaran dan metode pembuktian

Teknik pengumpulan data pada penelitian ini menggunakan metode dokumentasi. Teknik pengolahan dan analisis data dilakukan dalam tiga tahap yaitu reduksi data, display 
data, dan verivikasi. Reduksi data pada penelitian ini yaitu menganalisis soal-soal pada buku teks matematika Kurikulum 2013 edisi revisi berdasarkan indikator kemampuan penalaran matematika, dimana terdapat 4 indikator kemampuan penalaran matematika yang kemudian soal-soal tersebut akan diklasifikasikan memenuhi indikator 1, 2, 3, atau 4. Display data pada penelitian ini data akan disajikan dalam bentuk tabel sesuai dengan urutan BAB yang ada pada bukuteks matematika Kurikulum 2013 edisi revisi kelas XI, dengan soal-soal yang dianalisis akan diklasifikasikan dalam 3 kategori yaitu (1) memenuhi 1 indikator, soal kurang, (2) memenuhi 2 indikator, soal sedang, (3) memenuhi $>2$ indikator, soal baik. Verifikasi pada penelitian ini dilakukan dengan menarik kesimpulan menggunakan rumus presentase untuk menghitung jumlah dan persentase soalsoal yang membutuhkan penalaran matematika berdasarkan kategori yang telah disebutkan, kemudian dari hasil yang didapat diklasifikasikan lagi secara keseluruhan berdasarkan tabel berikut.

\begin{tabular}{ccc}
\multicolumn{3}{c}{ Tabel 1. Tabel Kriteria Presentase } \\
\hline No & Persentase & Kriteria \\
\hline 1 & $80 \%-100 \%$ & Sangat baik \\
2 & $70 \%-79 \%$ & Baik \\
3 & $60 \%-69 \%$ & Cukup baik \\
4 & $50 \%-59 \%$ & Kurang baik \\
5 & $0 \%-49 \%$ & Tidak baik \\
\hline
\end{tabular}

\section{Hasil Penelitian dan Pembahasan}

Secara umum, dari analisis yang telah dilakukan diketahui bahwa pada setiap BAB setidaknya terdapat 1 Uji Kompetensi dan untuk setiap Uji Kompetensi memiliki jumlah soal yang berbeda-beda. Jumlah soal yang ada pada buku teks matematika Kurikulum 2013 edisi revisi tahun 2014 kelas XI adalah 225 soal yang telah dianalisis berdasarkan indikator kemampuan penalaran dari NCTM.

Hasil penelitian berdasarkan analisis untuk setiap indikator kemampuan penalaran matematika mendapatkan bahwa ada 76 yang memenuhi indikator 1, 110 soal yang memenuhi indikator 2, 30 soal yang memenuhi indikator 3, dan 183 soal memenuhi indikator 4. Hasil analisis menyatakan bahwa soal-soal pada buku teks matematika Kurikulum 2013 edisi revisi tahun 2014 kelas XI lebih didominasi pada indikator 4 yaitu 183 soal yang memenuhi dari 225 soal, karena soal-soal pada buku tersebut lebih banyak mengarahkan siswa untuk meningkatkan kemampuan penalaran dengan menggunakan berbagai jenis penalaran dan metode pembuktian yaitu mengikuti aturan refrensi baik berupa rumus-rumus yang ada pada buku teks maupun pernyataan-pernyataan yang diberikan soal dan menggunakan metode pembuktian langsung. 
Hasil analisis juga menyatakan bahwa indikator 3 paling sedikit memenuhi soal-soal pada buku teks matematika Kurikulum 2013 edisi revisi tahun 2014 kelas XI yaitu sebanyak 30 soal dari 225 soal. Hal tersebut dikarenakan soal-soal pada buku tersebut belum banyak yang membutuhkan aspek mengembangkan dan mengevaluasi argumen, padahal seperti yang telah diketahui bahwa pada aspek mengembangkan dan mengevaluasi argumen merupakan salah satu aspek yang penting untuk membantu siswa meningkatkan kemampuan penalaran matematika. Kebanyakan soal-soal pada buku tersebut hanya mengarahkan siswa untuk membuat dan menyelidiki dugaan matematis (indikator 2) atau argumen dari soal-soal yang diberikan.

Hasil analisis berdasarkan kriteria kemampuan penalaran matematika mendpatkan bahwa terdapat 49 soal yang memenuhi kriteria baik dengan presentase 21,78\%, 80 soal memenuhi kriteria sedang dengan presentase 35,56\%, 88 soal memenuhi kriteria kurang dengan presentase $39,11 \%$, dan ada 8 soal yang bukanlah soal penalaran dengan presentase $3,56 \%$. Soal yang dianggap sudah benar-benar mencapai kemampuan penalaran matematika adalah soal yang memiliki kriteria baik, sedangkan soal yang memiliki kriteria sedang ataupun kurang belum sepenuhnya mencapai kemampuan penalaran matematika.

Soal yang memiliki kriteria sedang dan kurang dianggap belum sepenuhnya mencapai kemampuan penalaran matematika karena soal yang memiliki kriteria sedang hanya memenuhi 2 indikator dan soal yang memiliki kriteria kurang hanya memenuhi 1 indikator, dimana jumlah semua indikator adalah 4 dan soal-soal tersebut belum memenuhi lebih dari $50 \%$ dari indikator yang ada. Soal dengan kriteria sedang sebanyak 80 soal dan soal dengan kriteria kurang sebanyak 88 soal, apabila dijumlahkan soal yang memiliki kriteria sedang dan kurang adalah sebanyak 168 soal, sehingga sebanyak 74,67\% soal yang ada pada buku teks matematika Kurikulum 2013 edisi revisi kelas XI belum sepenuhnya mencapai kemampuan penalaran matematika. Soal yang memiliki kriteria baik merupakan soal-soal yang memenuhi sedikitnya 3 indikator kemampuan penalaran matematika, dimana jumlah semua indikator adalah 4 dan soal-soal tersebut sudah memenuhi lebih dari $50 \%$ dari indikator yang ada. Hasil analisis menyatakan bahwa soal yang memiliki kriteria baik berjumlah 49 soal sehingga sebanyak $21,78 \%$ soal yang ada pada buku teks matematika Kurikulum 2013 edisi revisi tahun 2014 kelas XI sudah benar-benar mecapai kemampuan penalaran matematika.

Berdasarkan penelitian ini buku teks matematika Kurikulum 2013 edisi revisi kelas XI menunjukkan terdapat $96,44 \%$ soal yang mendukung kemampuan penalaran matematika. Sehingga bila dilihat berdasarkan tabel kriteria yang telah dipaparkan, buku teks matematika Kurikulum 2013 edisi revisi tahun 2014 kelas XI sangat baik pada 
kemampuan penalaran matematika dan dapat disimpulkan bahwa buku tersebut sangat baik untuk digunakan oleh pendidik dalam upaya meningkatkan kemampuan penalaran matematika. Peneliti merekomendasikan penggunaan buku tersebut dalam proses pembelajaran sebagai sarana untuk meningkatkan kemampuan penalaran matematika siswa.

\section{Kesimpulan dan Saran}

\section{Kesimpulan}

Berdasarkan hasil analisis untuk setiap indikator kemampuan penalaran matematika, dari 225 soal yang ada pada buku teks matematika Kurikulum 2013 edisi revisi tahun 2014 kelas XI diperoleh 76 soal yang memenuhi indikator 1, 110 soal memenuhi indikator 2, 30 soal memenuhi indikator 3, dan 183 soal memenuhi indikator 4.

Hasil analisis juga memperoleh bahwa pada buku teks matematika Kurikulum 2013 edisi revisi tahun 2014 Kelas XI berdasarkan kriteria kemampuan penalaran matematika, dari 225 soal yang dianalisis hanya terdapat 8 soal yang tidak memenuhi indikator kemampuan penalaran matematika dengan presentase 3,56\%. Sedangkan sisanya ada 217 soal yang memenuhi indikator kemampuan penalaran matematika dengan presentase $96,45 \%$, dengan rincian 49 soal dengan presentase 21,78\% memiliki kriteria baik, 80 soal dengan presentase $35,56 \%$ memiliki kriteria sedang, dan 88 soal dengan presentase $39,11 \%$ memiliki kriteria kurang.

Hasil menunjukkan angka yang sangat tinggi terhadap soal-soal yang dianalisis berdasarkan kemampuan penalaran matematika yaitu 96,45\% dimana berdasarkan tabel kriteria yang telah dipaparkan masuk pada kriteria sangat baik, sehingga dapat disimpulkan bahwa buku teks matematika Kurikulum 2013 edisi revisi tahun 2014 kelas XI sudah mengarahkan siswa untuk meningkatkan kemampuan penalaran matematika dan sudah baik untuk dijadikan pedoman dan pegangan siswa dalam proses pembelajaran.

\section{Saran}

Dari hasil penelitian ini dapat diajukan saran-saran sebagai berikut:

1. Bagi guru

a) Buku teks matematika Kurikulum 2013 edisi revisi tahun 2014 kelas XI dapat dijadikan pedoman dalam proses pembelajaran untuk meningkatkan kemampuan penalaran matematika siswa dilihat dari hasil analisis yang sangat baik pada kemampuan penalaran matematika. 
b) Soal-soal pada buku teks matematika Kurikulum 2013 edisi revisi tahun 2014 kelas XI dapat dijadikan acuan dalam pemilihan soal-soal sebagai latihan siswa untuk meningkatkan kemampuan penalaran matematika

2. Bagi penulis dan penerbit buku matematika, hasil dari penelitian ini dapat dijadikan masukan dalam merevisi buku teks matematika kurikulum 2013 dalam pembuatan soal terutama pada aspek kemampuan penalaran matematika.

3. Bagi peneliti lain yang mengambil penelitian sejenis

a) Hasil penelitian ini dapat dijadikan acuhan dan masukan untuk menambah wawasan dalam pengembangan penelitiannya

b) Penelitian ini hanya ditinjau berdasarkan indikator kemampuan penalaran matematika sehingga perlu pengembangan ditinjau dari aspek yang lain

\section{E. Daftar Pustaka}

Adilah, Nurul. 2015. Analisis Soal dalam Buku Siswa Matematika Kurikulum 2013 Kelas VIII Semester I Berdasarkan Dimensi Kognitif dari Trends in International Mathematics and Science Study (TIMSS). Skripsi. Semarang: Universitas Islam Negeri Walisongo Semarang

Kemendikbud. 2012. Dokumen Kurikulum 2013

Kemendikbud. 2014. Matematika. Jakarta: Kementrian Pendidikan dan Kebudayaan

Mustofa. Tt. Kajian Kurikulum dan Buku Teks Ekonomi. Modul Mata Kuliah Universitas Negeri Yogyakarta

National Courcil of Theachers of Mathematics. 2000. Principles and Standards for School Mathematics. Reston: NCTMNikawanti, Gia. 2013. Pengembangan Isi Kurikulum. http://gianikawanti87.blogspot.co.id/2013/01/pengembangan-isikurikulum_3870.html?m=1. Diakses pada 30 Maret 2017

Rosita, Cita Dwi. Kemampuan Penalaran dan Komunikasi Matematis: Apa, Mengapa, dan Bagaimana Ditingkatkan pada Mahasiswa. Universitas Swadaya Gunung Jati Cirebon. Jurnal Euclid Vol.1 No.1

Sukayasa. 2009. Penalaran dan Pemecahan Masalah dalam Pembelajaran Geometri. Prosiding Seminar Nasional Penelitian Universitas Negeri Yogyakarta.

Utami, dkk. 2014. Kemampuan Penalaran Matematis Siswa Kelas XI IPA SMA N 2 Painan Melalui Penerapan Pembelajaran Think Pair Square. Jurnal Pendidikan Matematika Vol.3 No.1 